\title{
Látásnevelés korai gyermekkorban
}

\section{Dr. Földiné Angyalossy Zsuzsánna}

Fővárosi Pedagógiai Szakszolgálat Látásvizsgáló, Gyógypedagógiai Tanácsadó, Korai Fejlesztő, Oktató és Gondozó Tagintézménye, tagintézmény-vezető

A tanulmány célja a látás fejlődésének rövid ismertetése, a koraszülött- és kora gyermekkori látásproblémák bemutatása. Az orvosi, védőnői vizsgálatok kiegészítöje az ún. funkcionális látásvizsgálat, eredménye segíti a megkésett vizuális fejlődésü, illetve érzékszervi fogyatékos gyermekek látásnevelését. A látásnevelés integrált része a játéknak és a terápiának.

Kulcsszavak: látásfejlődés, látásproblémák, szemészeti szürés, funkcionális látásvizsgálat, látásnevelés

„A látás és megértés öröme a természet legnagyszerübb ajándéka.”

(Albert Einstein)

A látásnevelés szerepének megértéséhez szükség van arra, hogy röviden megismerjük a látás fejlődését, azt, hogy ki és milyen szempontok szerint ellenőrzi, hogy jól lát-e a gyermek, illetve arról is szót kell ejteni, hogy gyógypedagógiai módszerek segítségével, hogyan történik meg a csecsemök, kisgyermekek pedagógiai szempontú látásvizsgálata. Ez a vizsgálat lesz az alapja annak a fejlesztő munkának, amely a rászoruló gyermekek számára nélkülözhetetlen látásuk optimális kihasználásához.

\section{A látás fejlődése}

Az újszülött (0-3 hónap) baba pupillái egyenletesen sötétek, kerekek, szimmetrikusak, látja a fényforrást, az arcokat, fejjel és szemmel fordul feléjük. Erős fényre (napfény) hunyorog. Az oculo-palpebrális reflex 2-3 hetes gyermeknél kiváltható. Kezdetben nincs tárgykövetés, a szemmozgások koordinálatlanok. 4-8 hetesen felveszi a szemkontaktust és arckifejezéssel reagál rá; a lassan mozgó tárgyakat követi egy szemmel, rövid ideig két szemmel - elöször vízszintesen, később függölegesen is. A 2. hónap végére a mozgó dolgok és az élénk színű tárgyak iránt is érdeklődik, keresi a fényt, s a mozgó fény is felkelti érdeklődését.

3-6 hónaposan felfedezi a kezeit, nyúl a tárgyak felé, majd nyúl a felfüggesztett tárgyak felé is. Nézi a leeső és elguruló tárgyakat. A vizuális érdeklődése fokozatosan bővül: mozgó tárgyat fej-és szemmozgással már 180 fokban képes követni, kedveli az élénk színeket, követi az elveszett játékot - a szem-kéz koordináció kialakul: nyúl az eldobott játék után; zaj irányába pillant; érdeklődik az egy méternél nagyobb távolságban lévő vizuális ingerek iránt is; figyeli saját kezét vagy a kezében levő csörgőt. Szeret mindenkivel kommunikálni és nézni az illető arckifejezését. 4 hónaposan a szemmozgásoknak összerendezetteknek kell lenniük, $\mathrm{s} 6$ hónapos korban megkezdődik a térlátás tanulása is.

7-10 hónaposan észreveszi az apró tárgyakat (pl. morzsa), nyúl értük. Elöször megérinti azokat, majd meg is ragadja. Szereti az egyszerü rajzokat nézegetni, és felismeri azokat a tárgyakat is, amelyek csak részben látszanak. Felismeri a családtagokat anélkül, hogy szólnának valamit és széles mosollyal üdvözli, ahogy meglátja őket.. Idegenektöl egy kicsit tart, akkor is, ha mosolyognak. 
A11-12 hónapos gyermek szeret bújócskázni. Ismeria környezetében lévő dolgokat. Azablakonkitekintvefelismerembereket.Kezdképeketfelismerni.Mindentaszájábatévefedezfel-sígyrakjaösszeazegyeselemeket.Szemevízszintes, függőlegesiránybaismozog, a két szemes látás még gyenge, de már jól megkülönböztet egyszerü geometriai mintákat. Az egyéves gyermek vonalakat képes rajzolni, szívesen nézeget képeket, formákat azonosít, s egyre jobban képes a távolságok felbecslésére.

18 hónaposan egyszerű puzzle-t kirak. Érdeklik a könyvek és képek, felismeri, hogy a képek valós tárgyakat ábrázolnak. Szereti, ha rajzolnak neki, s történeteket füznek hozzá. Ismeri a tárgyak, képek nevét, képes megtanulni a Lea ábrák elnevezését: alma, ház, labda és négyzet (ez fontos a funkcionális látásvizsgálathoz). Formai és szerkezeti szempontból még nem beszél jól, de a családtagok, ismerősök megértik őt.

24 hónapos korában szeret firkálni és színezni. Megérti, hogy a képek lehetnek nagyok és kicsik, és mégis mindig ugyanazt ábrázolják. Csoportosítani tud hasonló dolgokat. A gyermek látásteljesítménye játék közben tesztelhető a legjobban - ha kedve tartja. Kis képeket is felismer jobb és bal szemmel egyaránt. Ebben a korban a látásélessége azonos a felnőttekével.

A 3 éves gyermek szemgolyójának mérete eléri a felnőttkori méretet.

7 éves korra kialakul a felnőttkori térlátás is, mely 12 éves kor körül a binokuláris látás fejlődésének befejeztével véget ér.

A legtöbb gyermek látása probléma nélkül fejlődik. Néhány egészséges és sok fogyatékos gyermeknek viszont orvosi kezelésre, fejlesztésre van szüksége a korai látásfejlődéshez. Ha felmerül annak a gyanúja, hogy a gyermek nem lát jól, célszerü minél előbb ellenőrizni azt. A korán felismert látási problémák egy része kezelhető még azelőtt, mielőtt csökkenne a látásélesség.

Figyelni kell a gyermek vizuális fejlödésére - különösen az első életévben. Ha a kívánt fejlődési mérföldköveket nem követi a baba, akkor beszélni kell a gyermekorvossal. A normál vizuális fejlődéstől való eltérés korrigálható, pl. szemüveggel, tréninggel, gyógyszeresen vagy éppen mütéttel.

\section{Eltérő fejlődésmenet - jelek, melyek látássérülésre utalnak}

Rizikófaktorok:

- a családban előforduló, anamnézis alapján megismert szemészeti megbetegedések, rendellenességek (pl. retinoblastoma, cataracta, glaucoma, anyagcserezavar, genetikai rendellenesség, retinadistrophia, amblyopia, kancsalság, fénytörési hiba, nem sérülés okozta vakság)

- a várandós krónikus betegsége (pl. gyógyszert szed)

- a várandóság alatt elszenvedett trauma, betegség

- dohányzás; alkohol-/drogfogyasztás

- bántalmazó/elhanyagoló család

- koraszülöttség

- intrauterin retardáció

- perinatális károsodás

- neurológiai rendellenesség

- craniofaciális abnormitás

Gyermekkori szemészeti megbetegedések, melyek egy része már újszülött, illetve csecsemőkorban is látható, kimutatható:

- anophthalmia (szemhiány)

- amaurozis (teljes vakság a látóideg gyengesége miatt, a szem látható, jelentősebb kóros elváltozása nélkül - fekete hályognak nevezik)

- microphthalmia (kisszemúség) 
- duzzadt szemhéjak

- könnycsatorna-szükület, -elzáródás - fokozott könnyezés

- fokozott váladékozás

- buphthalmus (a szemgolyó megnagyobbodásával járó veleszületett zöldhályog)

- glaucoma congenita (veleszületett zöldhályog)

- cataracta congenita (veleszületett szürkehályog)

- phtosis (szemhéjcsüngés)

- coloboma iridis (a szivárványhártya hasadéka, szövethiánya)

- aniridia (a szivárványhártya hiánya)

- albinizmus (veleszületett festékanyaghiány)

- strabizmus (kancsalság) - 4-6 hónapos korban már kóros (!), az orvosi előírásnak megfelelő takarás szükséges az ép szemen

- fénytörési hibák

- myopia (rövidlátás) - a szemtorna is segít

- hypermetropia (távollátás, túllátás) - 2-4 éves kor körül eleinte csak betegség, fáradtság idején jelentkező összetérő kancsalság hívja fel rá a figyelmet

- astigmia (sugárgyűjtési hiba)

- színlátászavar

Milyen jelek alapján forduljon a szülő/háziorvos/védőnő gyermekszemészhez?

- hályog, kis-, ill. nagyszemüség esetén (cataracta, glaucoma, microphthalmus, buphthalmus)

- ha a szürések során megállapítást nyer, hogy a gyermek korának nem megfelelő a látásélessége

- kancsalság (strabizmus) figyelhető meg

- nem vesz fel szemkontaktust

- nem érdeklik a feltűnő, színes tárgyak sem, nem szeret képeket, képeskönyvet nézegetni

- nem néz a mutatott irányba, nem keresi az elguruló tárgyakat

- figyelmen kívül hagyja az apró tárgyakat

- nehezen követi a mozgó tárgyakat

- ferde fejtartással fixál

- mozgása megkésett, ügyetlen

- fél mászni, ugrani

- $\quad$ nem szereti a mozgásos játékokat, ügyetlen, nehezen tájékozódik

- a hangot adó, nagy formátumú játékokat kedveli

- szeret egy helyben ülni, játszani - ragaszkodik a helyváltoztatáshoz kísérőre

- nem szívesen viseli a szemüvegét, vagy felette néz ki

- fejfájós

- gyakran könnyezik

- fényre érzékeny

- gyakran van kötőhártya gyulladása

- kettős látásról panaszkodik

- Iskoláskorban:

- gyakran dörzsöli a szemét, hunyorgat

nem tudja követni a táblára írtakat

másolásban pontatlan

tekintete nem célirányos

a betűformákat csak nagyított formátumban ismeri fel

betűket cserél

vonalvezetése határozatlan - nem alakítja megfelelően a betűket, számokat

pontatlan a betükapcsolása, elhagyja az ékezeteket

a normál füzetek vonalközébe nem tud írni

- nem tud megfelelően utánozni

- balesetet követően

- daganatos megbetegedésekkor (agydaganat, arcüregi daganat, retinoblastoma) 


\section{Szemészeti szúrővizsgálatok}

A látássérülés (érzékszervi fogyatékosság) felismerésében és a szakszerű ellátás minél korábbi életszakaszban történő megkezdésében segítségünkre vannak a szemészeti klinikák, a kórházak és szemészeti rendelők, védőnők, gyermekorvosok a családsegítőkben, gyermekjóléti szolgálatnál dolgozó szakemberek, intézmények vezetői, (gyógy)pedagógusai és nem utolsó sorban a szülők.

Az orvos az újszülötteknél megfigyeli, hogy reagálnak-e az erős fényre; 1 hónapos gyermeknél figyel arra, hogy van-e nystagmus vagy naplemente-tünet; 2 hónapos baba esetében vizsgálja, hogy figyel-e emberi arcra, netán sakktáblamintás lapra; a 4 hónapos csecsemőnek már képesnek kell lennie arra, hogy a látóterébe kerülő tárgyak után nyúljon és megfogja azokat, valamint megvizsgálja őket mind vizuálisan, mind taktilisen, mind orálisan; 6 hónaposan a tárgyat átveszi egyik kezéből a másikba, a leeső tárgy után néz, lehúzza fejéről a rátett kendőt; 9 hónapos korában már kedveli a kukucs-játékot, tekintetével megkeresi a megnevezett tárgyakat.. Ettől a kortól kezdődően még fokozottabban kel figyelni arra, hogy nem néz-e közelről mindent, látja-e az apró dolgokat is, észreveszi-e ha közelít felé valaki, illetve tiltakozik-e az ellen, ha az egyik szemét letakarják.

A védőnő a látószervek megfigyelésén túl szintén megnézi, hogy reagálnak-e a pupillák a fényre; követi-e a mozgó személyeket, tárgyakat; 2 hónaposan a válla közötti szélességben tekintetével, oldalra fordított fejjel figyeli-e kezeit, ujjainak mozgását; a követés, a középvonalba hozott kéz-tárgy nézegetése, a párhuzamos szemállás megfigyelése a következő életszakasz feladata; 6 hónaposan már párhuzamos szemállás mellett távolabbi dolgokat is megkeres a csecsemő és figyel a leeső tárgyra, odanyúl, ahová néz - ezek megfigyelése a bénulásos kancsalság kizárására is irányul, illetve jelzés-értékű, ha a gyermek az egyik szem takarása ellen tiltakozik; 9 hónapos kor táján a szem-kéz koordináció ügyetlensége, a tárgyak fixálási nehézsége, illetve a követés hiánya is utal arra, hogy baj van a gyermek látásával; az 1 éves gyermek 3-5 méterre jól fixál, a két szemmel látott tárgyak képét már idegrendszeri tevékenység következtében formálja képpé - megfigyelésre kerül az, hogy mozgása korának megfelelő-e, apróbb tárgyakat, képeket felismer-e, kérésre rámutat-e egyszerübb képekre, illetve a pupilla középen áll-e és szimmetrikusan tükröződik-e a lámpa fénye, s nem nézi-e nagyon közelröl a dolgokat; a következő életkorokban is nagy szerepe van a következő megfigyeléseknek: pislog-e sokat a gyermek, hunyorog-e gyakran, nincs-e „érdekes” fejtartása nézéskor. A látásélesség vizsgálata 3M ábrák használatával történik, jelzés-értékü, hogy a felismert tárgyak mérete mekkora, a pupilla-reakció adekvát-e, a sztereólátás (mélységérzés) megfelelő-e (Lang II. teszt), valamint a takarásos teszt elvégzése (rejtett kancsalságra utaló jelek megfigyelése) és a vörösvisszfény-vizsgálat is lényeges.

A látásélességre (Vizus), illetve kancsalságra (strabizmus) vonatkozó vizsgálatokat a háziorvosoknak, iskolaorvosoknak, védőnőknek kell elvégezni. A tompalátás (amblyopia) észlelésének leghatásosabb módszere is a megfelelő időben elvégzett szürővizsgálat.

A vizsgálatokat követően, amennyiben eltérő fejlődésmenetet észlelnek, akkor célszerü a gyermeket elküldeni az illetékes szakszolgálathoz, hogy bebizonyosodjon, vagy elvetésre kerüljön az a megállapítás, hogy sérült a gyermek látása.

Modern szemlélet szerint a hazánkban ismert kategóriák (vak, aliglátó, gyengénlátó) nehezen különíthetők el, hiszen a vizuális funkciók és funkcionális területek megítélése függ a körülményektöl, a feladat jellegétől és a személy aktuális ál- 
lapotától is. Lehet valaki például nappali fényben jól közlekedő, de sötétedéskor vagy rossz megvilágításban vak embernek látszik - ezért egyik kategóriába sem sorolható. A pedagógiai látásvizsgálat segít kiegészíteni az orvosi és védőnői szüréseket, s utat mutat a további teendőkre vonatkozóan.

\section{Funkcionális látásvizsgálat és eszközei}

A látóképességre az egyéni reakciókból lehet következtetni. Fontos megismerni az anamnézist (kórelőzmény, diagnózis/ok/ - pl. progrediáló-e a szembetegsége, milyen kezeléseken, mütéteken esett át, más és más fényviszonyok között változik-e a látásteljesítménye) a látóképesség gyengeségére/hiányára utaló jeleket, a rizikófaktorokat és a szülői megfigyelésen alapuló információk mibenlétét, valamint figyelni kell a gyermek életkorára, egyéb sérüléseire, pszichés állapotára, értelmi képességeire, szociokulturális hátterére. Ezek lesznek a kiindulópontjai a gyógypedagógiai, azaz funkcionális látásvizsgálatnak.

„A funkcionális látásvizsgálat során megfigyeljük a gyermek praktikus élethelyzetekben megmutatkozó látásteljesítményét, valamint életkora és képességei adta lehetőségek szerint megvizsgáljuk vizuális funkcióit. A látás megfigyelése inkább a szubjektív, a tesztek eredménye inkább objektív információval szolgál (egyik sem tisztán szubjektív vagy objektív, hiszen az egy-egy megfigyelt jelenség lefordítható objektív adattá, miközben a tesztelés értékelésébe is belejátszik a szubjektív tényező). A megfigyelés és a mért eredmények összevetése mutatja meg, hogy a gyermek kihasználja-e a látórendszerében rejlő lehetőségeket, vagy eszközökkel, a környezet átalakításával és fejlesztéssel segíteni kell a lehetőségekhez képest maximális látásteljesítmény kiaknázásában (Gadó, 2008). Vannak gyermekek ugyanis, akik nagyon rossz látási funkcióikkal is biztosan mozognak, ügyesen manipulálnak, tárgyakat és képeket jól felismernek, az ő vizuális hatékonyságuk maximális (Gadó, 2004). Akkor van szükség gyógypedagógus fejlesztésére, ha a mérhető jobb értékek lehetőségéhez képest a gyermek praktikus müködése sokkal rosszabb látásteljesítménynek megfelelö képet mutat.

A tesztek használata, az objektív vizsgáló eljárások alkalmazásának elsődleges célja tehát nem a látásteljesítmény abszolút értékének megmérése, hanem az említett vizuális hatékonyság feltérképezése, valamint a nyomon követés érdekében az összehasonlítható adatok biztosítása. A gyengénlátó gyermekek többségénél a vízus értéke az évek során valamelyest emelkedik, mivel az idegrendszer érése a figyelem, koncentráció fejlődése a látott jelek egyre jobb értelmezését, és így valamelyest javuló vízust eredményez. Ezért különösen szembetűnő és fontos felfigyelni az esetlegesen romló vízusra, amely egy előrehaladó kóros állapotot jelezhet, amellyel fontos időben szemészorvoshoz fordulni." (Földiné, Gadó és Prónay, 2012. 18. o.)

A vizsgálat kiterjed a következőkre:

- közeli és távoli látásélesség vizsgálata

- a kontrasztérzékenység vizsgálata

- a fényviszonyokhoz való alkalmazkodás képessége - adaptáció

- a látás agyi feldolgozásának funkciója - kérgi problémák

A pedagógiai (funkcionális) látásvizsgálat célja tehát annak megállapítása, hogy milyen speciális eszközökkel és módszerekkel segíthetők a látássérült gyermekek tanulási folyamatai, hogyan fejleszthető a látás. A látásvizsgálatot végző gyógypedagógus a látásélességen kívül egyéb szempontokat (képességeket, körülményeket) is figyelembe vesz. 
„A vizsgálat során a két szem vízusát külön-külön is mérik, de a két szem együttes látásteljesítménye sok esetben jobb lehet ennél. Olyan mérőjeleket, eszközöket használnak, amelyekkel a gyermek a vizsgálat elött megismerkedhet, azokat kézbe veheti, gyakorolhatja az irányok mutatását - így könnyebben megérti és teljesíti a feladatot.

Csecsemö- és kisgyermekkorban a szemész szakorvosi vizsgálat nem mindig sikeres a hagyományos módon, így más módszereket alkalmazva kell meggyőződni arról, hogy mire reagál a gyermek: fényre, arcokra, tárgyakra és azok méretére, színére stb.

A funkcionális látásvizsgálat eredményeképpen javaslatot tesznek olyan gyakorlatokra, eszközökre, illetve előállításukra, melyekkel a látásnevelés/látásfejlesztés megvalósulhat otthoni, illetve intézményes keretek között." (Földiné, Gadó és Prónay, 2012. 40-41. o.)

Reakció fényre - a fényhez való alkalmazkodás vizsgálata: felfigyel-e rá, zavarja-e a direkt, erős fény; jobban felfigyel az olyan tárgyakra, amelyeket megvilágítunk, követi-e a fényt; szívesebben nézelődik félhomályban.

\section{Látásélesség (távoli és közeli) vizsgálata:}

Csecsemőknél az ún. Preferential Looking Test segít abban, hogy a látásteljesítményt meghatározhassák - alapja az, hogy a csíkos ábrák jobban felkeltik a gyermek figyelmét - tekintetét arra irányítja.

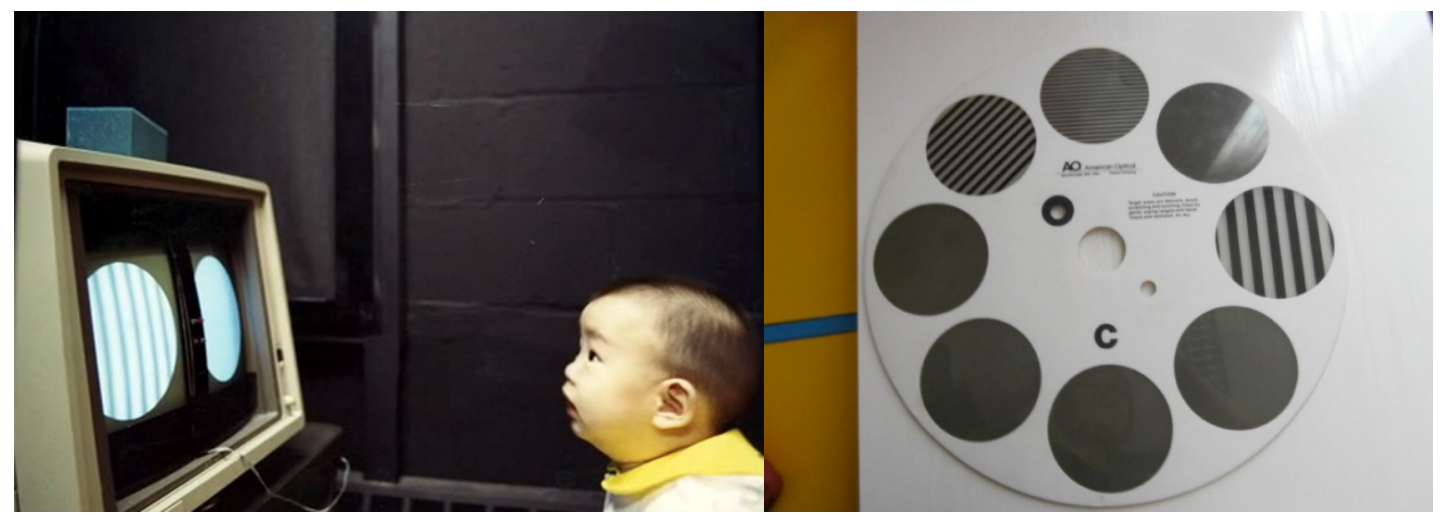

1. kép: Preferential Looking Test - www.perkins.org/ tárcsa a teszthez (fotó: Földiné)
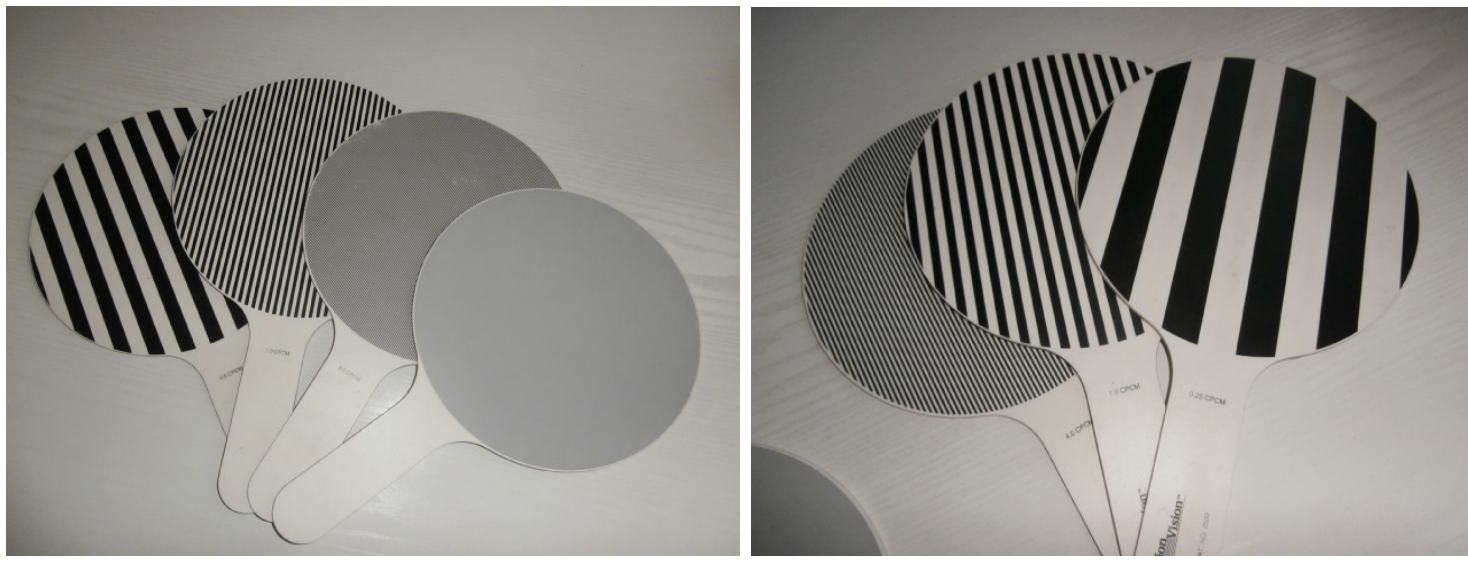

2., 3. kép: A Preferenciális Látás Tesztje (Hyvärinen) (fotó: Földiné)

Ezt követően elsősorban ábrák segítségével lehet meghatározni a gyermek látásélességét. A Lea Hyvärinen által kifejlesztett eszközök használata segít a megha- 
tározásban. A gyermeknek a ház, négyzet, kör és alma formákat kell felismernie. A felismerés begyakorlására ad lehetőséget az alábbi játék, mely mellett az ábrasor is megtekinthető:

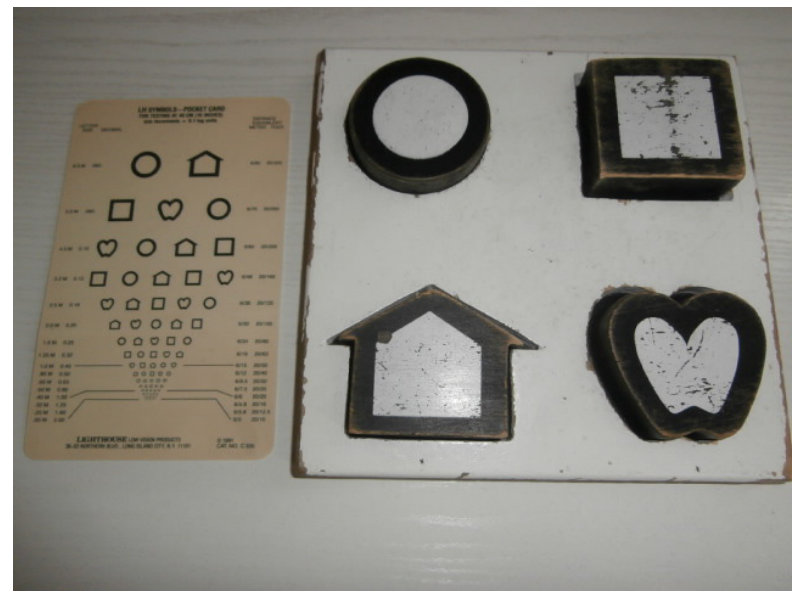

5. kép: A vízustábla és az ábrák megtanítását segítő kirakó (Hyvärinen) (fotó: Földiné)

A kontrasztérzékenység az alak és háttér elkülönítésének képessége - vizsgálatára alkalmas pl. a Hiding Heidi Teszt.

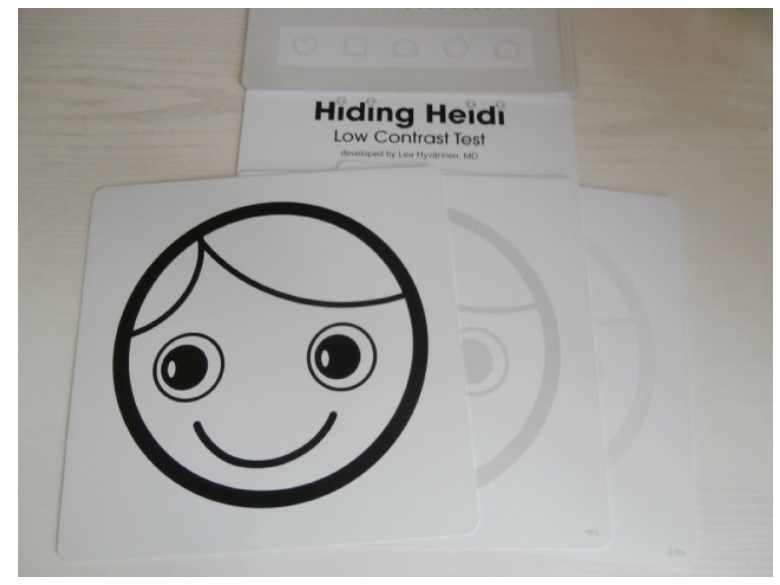

6. kép: Kontrasztérzékenységet vizsgáló Hiding Heidi Teszt (Hyvärinen) (fotó: Földiné)

\section{A látótér vizsgálata}

Gyermekeknél a konfrontális vizsgálat alkalmazható - a gyermek feje fölött, az álla felől, bal és jobb oldalról hoz be a vizsgáló lassan, fokozatosan a gyermek látóterébe egy tárgyat pl. ceruzát), miközben egyenesen elöre rögzíti a gyermek a tekintetét. $A$ gyermekkel szemben állunk, kartávolságnyira. Felszólítjuk, hogy nézzen ránk és igyekezzék tekintetét rögzíteni.

Többnyire olyankor végezzük, ha a gyermek diagnózisában vagy mozgásos viselkedésében csőlátásra utaló jelek vannak. 90 fokos látótér még gyakorlatilag normálisnak tekinthető, 60 fokon belül már beszűkültnek tartjuk, 30 fokon belül „csőlátásnak” nevezzük. 


\section{Színlátás vizsgálata:}

A színek felismerése, egyeztetése az alábbi tábla segítségével történhet:

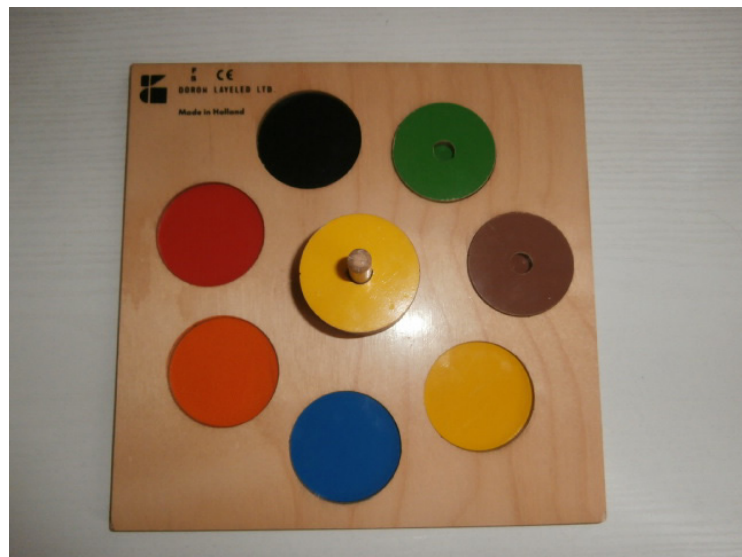

7. kép: Színlátás - színfelismerés vizsgálata kicsiknél (fotó: Földiné)

Nagyobbaknál a legelterjedtebb vizsgáló módszer az Ishihara-tábla használata, mely a színvakság vagy színtévesztés felismerését segíti elő. A táblákon azonos világosságú, de különböző színű és méretű kerek foltokból számok vagy betük rajzolódnak ki, vagy az eltérő színű pöttyöket lehet követni az ujjunkkal. A vizsgálatot természetes fényben célszerű elvégezni 30-50 cm-ről.

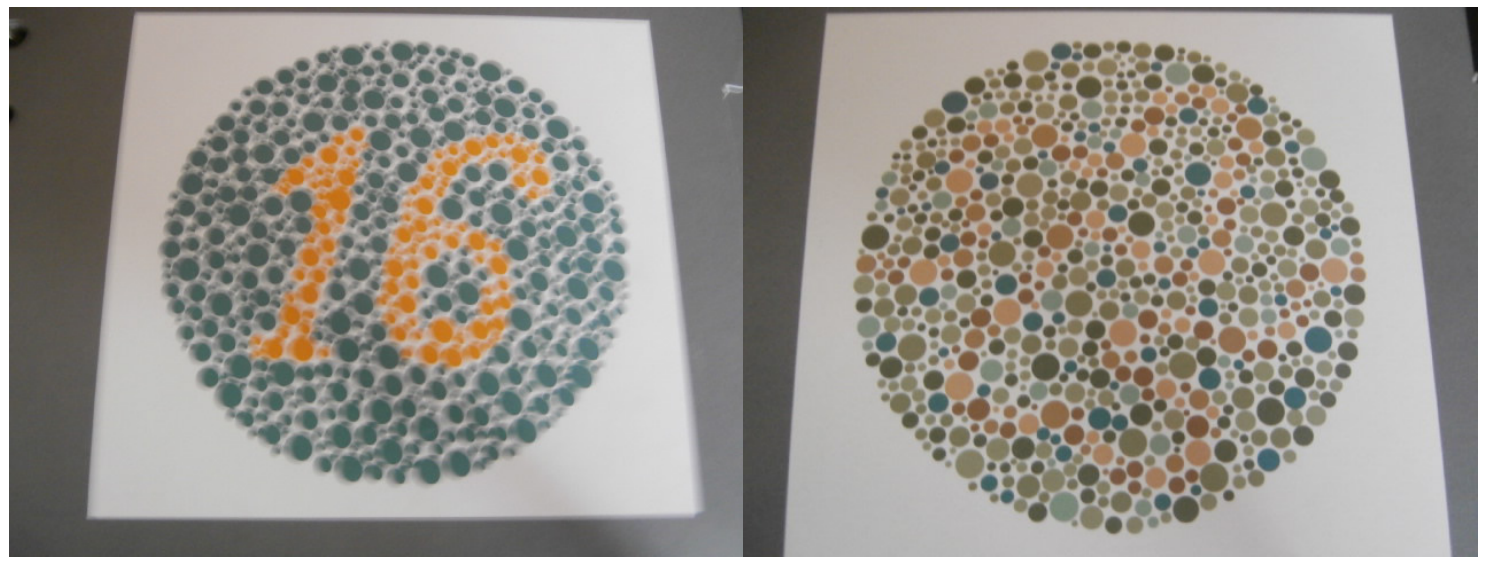

8., 9. kép: Pszeudo-izokromatikus ábrák - „pöttyös táblák”- (legismertebb az Ishihara)

\section{A látás agyi feldolgozásának funkciói}

„A látás agyi feldolgozásának kérdése az utóbbi években került a szakmai figyelem fókuszába, amióta egyre többet tudunk az agyi eredetű látássérülésről, és a szakma szembesül a probléma folyamatos gyakori elöfordulásával. Az agyi funkciók vizsgálatára nincsen egyértelmű teszt, a tünetek ismeretében kell figyelni a vizsgálat közben, hogy mutatja-e a gyermek a jellegzetes tüneteket (Gadó, 1997)." (Földiné, Gadó és Prónay, 2012)

A fentieken túl a szemmozgások között vizsgáljuk a fixáció, szemmel követés, pásztázás készségeit, valamint a kóros szemmozgások meglétét: van-e nystagmus (akaratlan szemmozgás) vagy a szemgolyó céltalan, úszkáló mozgása. 
További eszközök, melyet a gyakorlatban használunk vizsgálathoz és fejlesztéshez egyaránt

Lightbox (világító doboz: tárgyak - formák, alakok, képek láthatóságát növeli a megvilágítással)
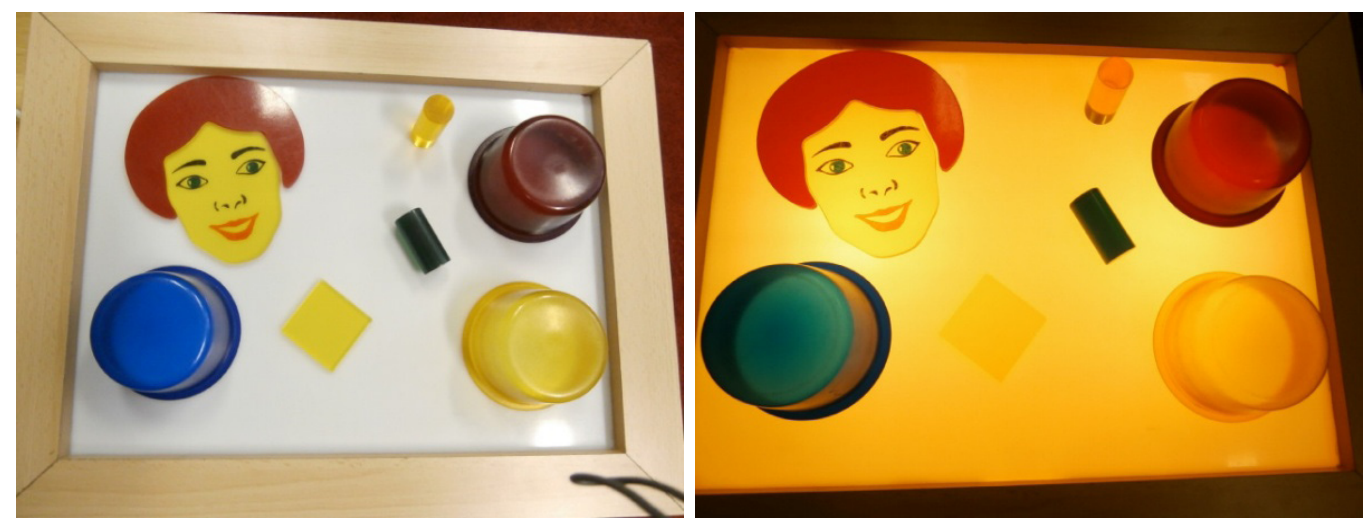

10., 11. kép: Világító doboz (Fotó: Földiné)

Olvasó TV: képernyőböl és egy hozzákapcsolt kamerából áll. A kamera alá helyezett tárgyat vagy képet a képernyőn kívánt nagyságúra nagyítva vetíti. Nagyítással olvashatóvá tehetők a szövegek (kézzel/géppel írt), tárgyak, elvégezhető a kamera alatt pl. a tübefüzés, írás; fokozható a kontraszt, változtatható a szöveg-háttér szín.

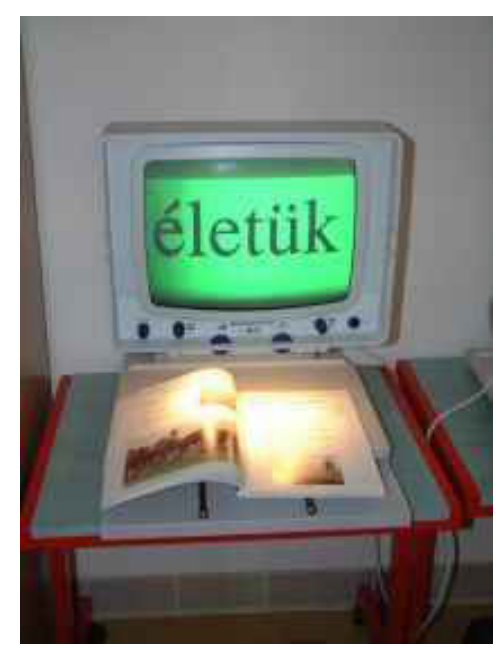

12. kép: Olvasó TV (vakokblaszlogyermekotthon.blog.hu)

- Nagyítók: kézi nagyító

- Elemlámpák: fény iránya, helye lokalizálható

- Számítógépes programok (pl.: a sen-switcher) 


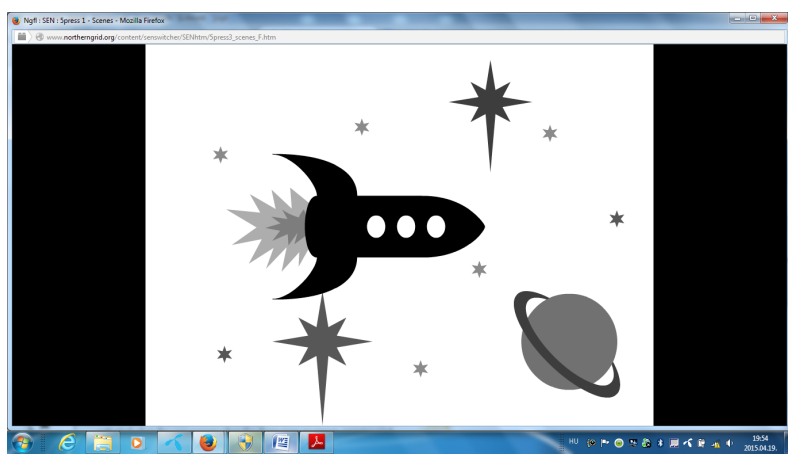

13. kép: http://www.northerngrid.org/resource/sen-switcher

- Színes tárgyak, eszközök

- Színegyeztető

- Képek - mesekönyvek

\section{Látásnevelés és eszközei}

A minimális látásteljesítménnyel rendelkező gyermek látásfejlesztése is szükséges. Előfordulhat, hogy orvosilag vaknak nyilvánított gyermek vizuális figyelme is felkelthető, cél, hogy fokozatosan legalább a fényre el kezdjen figyelni, s netán még tovább is fejlödjön, felismerjen, kövessen tárgyakat, személyeket. A látásneveléshez is szükség van arra, hogy a fejlesztő/szülö megtalálja azt az optimális testhelyzetet a gyermek számára, amely lehetővé teszi, hogy figyelmét a „feladatra” összpontosítsa. A környezete legyen színes, de ne túlzottan, legyen benne sok olyan tárgy, ami kontrasztos (pl. világos alapon sötét minta).

A látásnevelés során mindig figyelni kell arra, hogy játékos módon történjen, a gyermek ne érezze fárasztónak, hanem élvezze ezt a tevékenységet. A figyelem a korai fejlesztés időszakában még eléggé szórt, kismértékben terhelhető, ezért a többszöri, rövid időtartamú fejlesztés lesz hatékony. A látásnevelés a komplex korai fejlesztés része kell, hogy legyen.

Cél: A látás maximális kihasználása, szinten tartása és fejlesztése, az, hogy a gyermek spontán módon használja a többi érzékszerv által szerzett ismeretek kiegészítéséhez.

\section{Feladatok:}

- A pedagógiai módszerekkel mért látásteljesítmény folyamatos kontrollálása, a praktikus látás megfigyelése.

- Szisztematikus kompenzációs technikák tudatosítása: követő szemmozgás, tekintetváltás, pásztázás.

- Szem-kéz koordináció megalapozása, gyakoroltatása.

- Optimális megvilágítás, testhelyzet, fejtartás megtalálása.

- Az alulról megvilágított tárgyak felismertetése

- Nyúlás alulról átvilágított tárgyak után

- Az alulról megvilágított tárgyak közötti különbségek felismertetése nagyságuk, formájuk és színük alapján

- Kontrasztos helyzetben lévő tárgyak felismerése

- Világító dobozon egyszerű képek felismerése

- Tükörben testrészeinek felismerése

- Firkálás vastag filctollal, ceruzával 
Stimuláció fénnyel: álló és mozgó világítótestek (elemlámpa, zseblámpa, színét változtató, villogó, vibráló lámpák, hangulatlámpák, karácsonyi égősor, diavetítő, gyertya stb.) - természetes és mesterséges fények megfigyeltetése. A stimuláció erős ingerek adásával, jól strukturáltan és egyszerűen történjen. Alatta gondosan figyelni kell a túlstimulációra adott jelzéseket: megnövelheti a szívritmust, a légvétel gyakoriságát és megváltozhat az izomtónus.

\section{Eszközök:}

Játékszerek: Sok megszokott játékszer igen hasznos lehet, a kontrasztot fokozza, pl. ha zseblámpával megvilágítjuk a játékot egy félhomályos szobában.

Csillogó tárgyak: Fényes felületek, hogy a visszavert fényt erős ingerként használhassuk. Ha a tárgyak érdekes felületüek és néhány közülük pl. hangot is ad, akkor a csecsemő megtanulja az információk összekapcsolását.

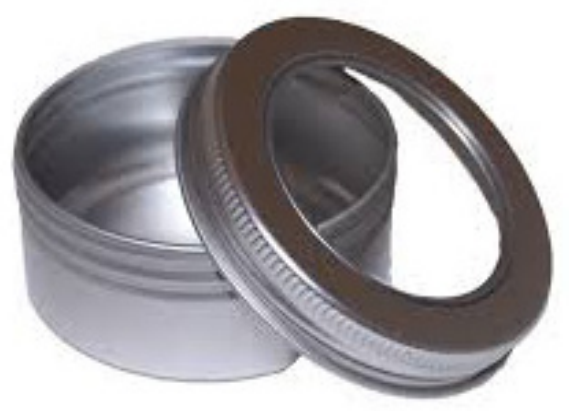

14. kép: shop.mozart-souvenir.hu

Csíkos felületek: PI. ha az üvegmelegítőt/cumisüveget fényes vagy sötét csíkokkal vonjuk be, akkor az a csecsemőt nézésre ösztönzi: lehet hallani a hangját, ahogy a folyadék az üvegben lötyög.

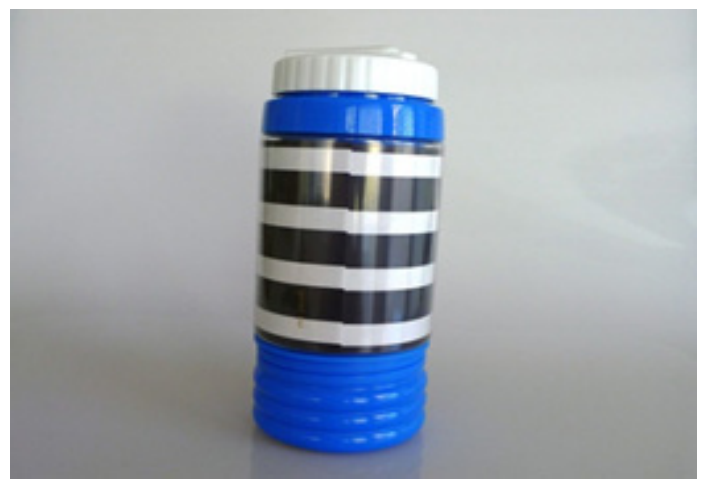

15. kép: http://www.evyjacob.com/products/kids-water-bottle-navy-stripes-personalized-1

Karácsonyi dekoráció: Az olcsó karácsonyi díszek, hatékony aktiválói a látássérült csecsemőknek, akiknek korlátozottak a motoros és szenzoros funkcióik. PI. egy megvilágított csillogó gyöngysor könnyen megfogható. Kellemes hangot ad, jó a tapintása, csillog, azaz kiváló stimuláló eszköz. A motoros funkciók zavara esetén, amikor a fej megtartása, a kezek mozgása korlátozott, akkor olyan eszközre (ék alakú szivacs) kell hasra fektetni a gyermeket, ami lehetővé teszi a kezek mozgását, és a fejének tartására ingerli - egy tálban elhelyezett megvilágított gyöngy után így képes lesz nyúlni, megfogni azokat. 


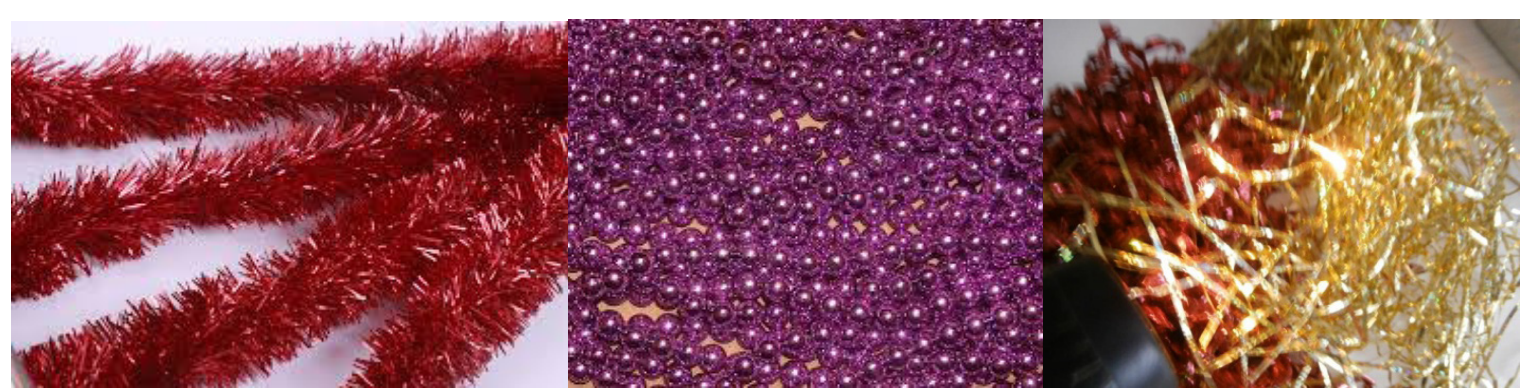

16. kép

Világító labda: belülről megvilágított eszköz, ami fixálásra, nyúlásra ingerli a gyermeket.

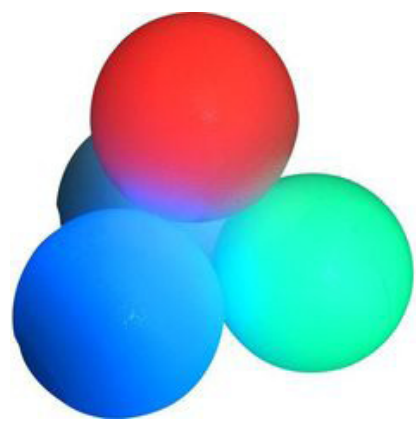

17. kép: www.pinterest.com

Színváltós labda/figura: villog, vagy színt vált - általában ütésre kezd el fényt adni - az ok-okozati összefüggések felismerésére ad így kitűnő alkalmat. A villogó eszközöket csak neurológus véleményének kikérése után szabad használni, epilepsziás gyermeknél nem tanácsolt.

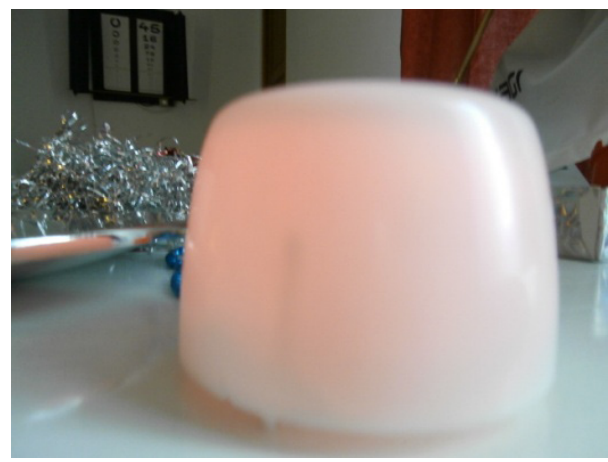

18. kép: (fotó: Földiné)

Világítódoboz:

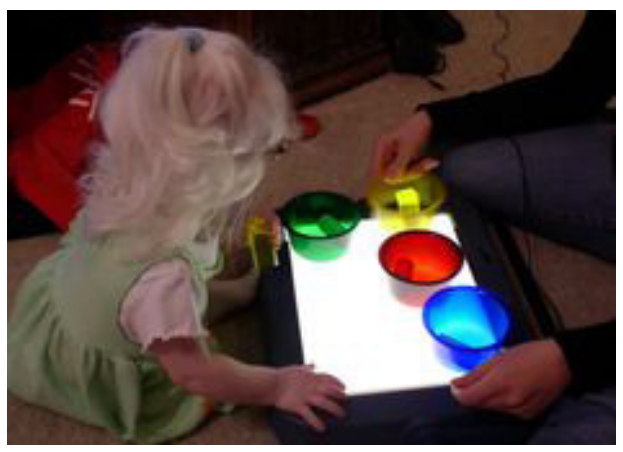

19. kép: www.pinterest.com 
Gyakorlatok (mondókákkal, énekkel kombinálva): a fény színe eleinte fehér (sárgás), majd színes lehet (színes fólia, előlap), illetve színes tárgyakat lehet átvilágítani (müanyag pohár, léggömb, építőjáték) - közben játszani is lehet ezekkel a tárgyakkal zörögnek, építeni lehet belölük, lehet dobni, gurítani stb.

- fény keresése, fixálása minden irányban, minden irányból (LED lámpa használata tilos!)

- fény követése, tekintetváltás: tekintet rögzítést követően lassú ütemben mozgatott fény követése vízszintes, függöleges, átlós és körkörös irányba. Nyúlás esetén kézbe veheti, s úgy tanulmányozhatja a világító eszközt, pl. az elemlámpát. 2 lámpa használatával a tekintetváltásra lehet ösztönözni a gyermeket - az éppen világítót kell fixálnia.

- fény-árnyék; játék a visszavert és színes fényekkel

- diavetítő, asztali lámpa használata: a világító doboz ki- bekapcsolásával, tárgyak ráhelyezésével (attól függően, hogy mi történik, lehet énekeket, mondókákat is mondani: eltakaráskor pl: Süss fel nap; úszkáló kacsákat keresgélve pl. Kis kacsa fürdik; stb.); átvilágított tárgyak keresése; fóliák mozgatása, fóliára rajzolt tárgyak felismerése, egyeztetése;

\section{Játék csillogó felületű, és élénk színủ tárgyakkal, mintázott tárgyakkal}

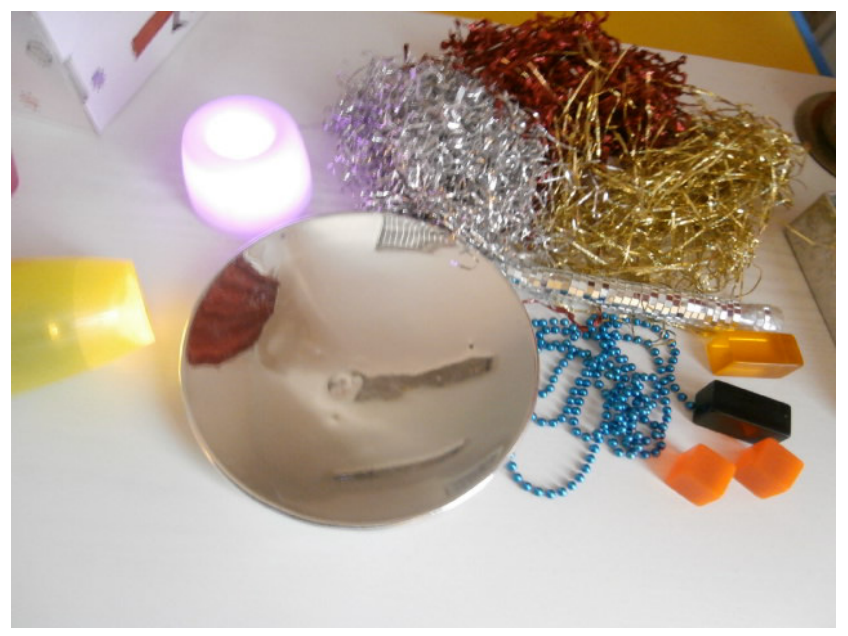

20. kép: (fotó: Földiné)

Színes, mintás szalagok, gyöngysor, karácsonyi díszek mozgatása, fújása - ösztönözve a gyermeket a nyúlásra.

Csillogó tapéta használata tárgyak bevonásához - pl. különböző magvakkal megtöltött flakonok bevonása - rázáskor hangélményt is nyújt.

Erős kontrasztot adó, csíkozott tárgyak nézegetése, mozgatásuk követése vízszintesen, függőlegesen, körkörösen, miután tekintetét rögzítette rajta. Amikor ez a játék sikeres, akkor lehet a kontrasztot csökkenteni, a csíkos felületeket képesre cserélni.

V. Vasarely képei is jó szolgálatot tesznek a látásnevelés során. 


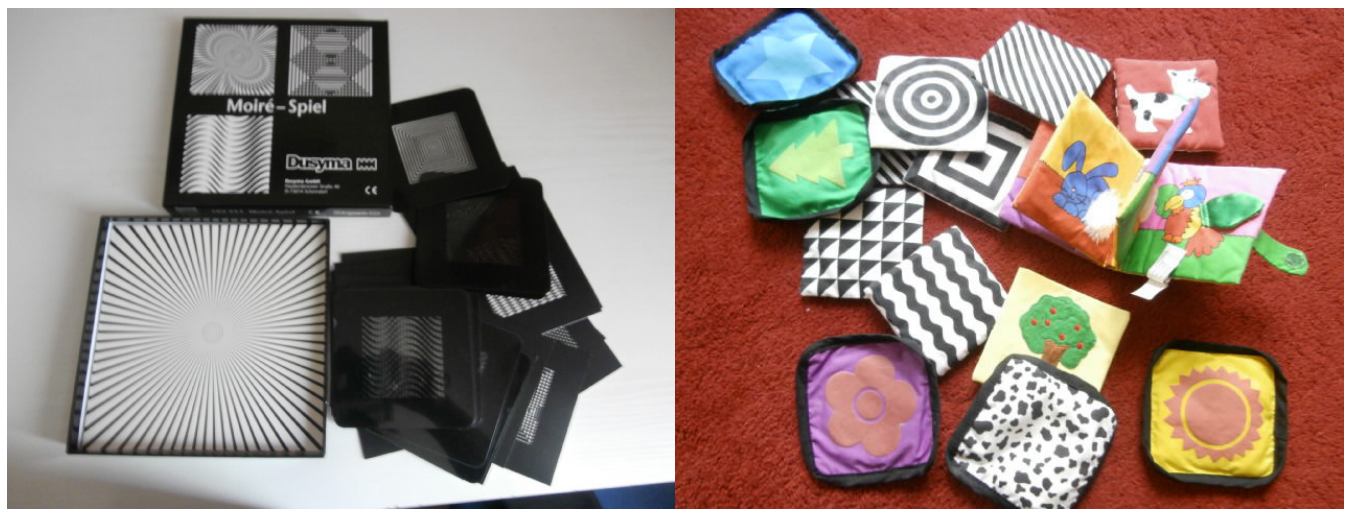

21., 22. kép: (fotó: Földiné)

A kicsik a mintázott kártyákat preferálják az üres lappal szemben: érdemes egy üres és egy mintázott lap egy időben történő mutatásával is felkelteni a figyelmét, engedve, hogy hosszasan pihentesse rajta a tekintetét.

A tekintetváltás gyakorlásához az egyszerü ábrákat, hétköznapi tárgyakat ábrázoló mesekönyvek kerülhetnek elő: mindig célszerü az eredeti tárggyal összevetni, s minden érzékszervre hatni általa.

Kedvence lehet a gyermekeknek a különböző felületekre elhelyezett kontrasztos, élénk színű mintás lap, ábra - matrica. Lehet, keresni - rámutatni, későbbi életkorban megnevezni stb.

\section{Vizuális alapfunkciók fejlesztése tárgyakkal}

A tárgyakat, fényeket mindig több irányból kínáljuk fel a gyermeknek a lokalizálás gyakorlása során.

Bújócska-kukucs-játék még a csak fényt érzékelő gyermek számára is élvezetes.

A fixálás gyakorlásához használható eszközök lehetnek pl. a búgócsiga, pörgetytyűk, lejtős pályán mozgó golyók, farúdon mozgó harkály stb.

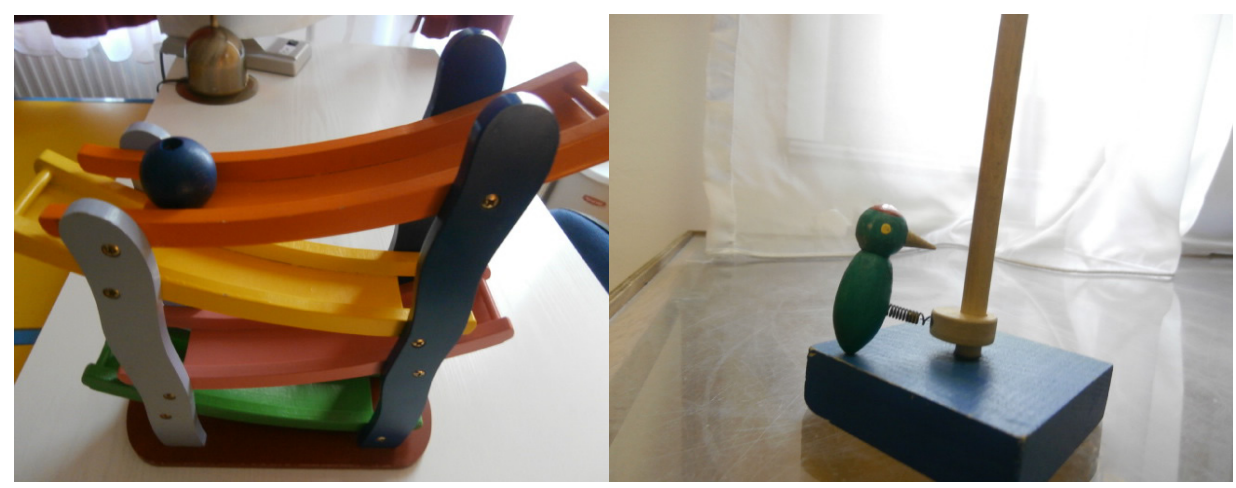

23., 24. kép: (fotó: Földiné)

A mindennapi életben használt tárgyak felismertetése először teljes méretben, majd részletei alapján - engedjük, hogy alaposan nézze meg mindet.

A szappanbuborékok fújása - követése kitűnő nyári, szabadidős tevékenység.

Színes vonalak, minták szemmel - ujjal követése izgalmas játék a kicsinyek számára.

A labda gurítása, pakolás egyik helyről a másikba mind, mind a tekintetváltásra ösztönöz. 
Pakolás egyik tálból a másikba. Összeköthető étkezéssel is: tálból a szájba kell tegye pl. a kölesgolyót, mazsolát.

Járművek garázsba állítása, magok ültetése is a fentebbi célokat szolgálja.

Pásztázáshoz szórjunk szét tárgyakat, feladat azok összegyűjtése. Közben megfigyelhető, hogy milyen nagyságú tárgyakat talál meg könnyen, s, hogy pontosan nyúl-e értük.
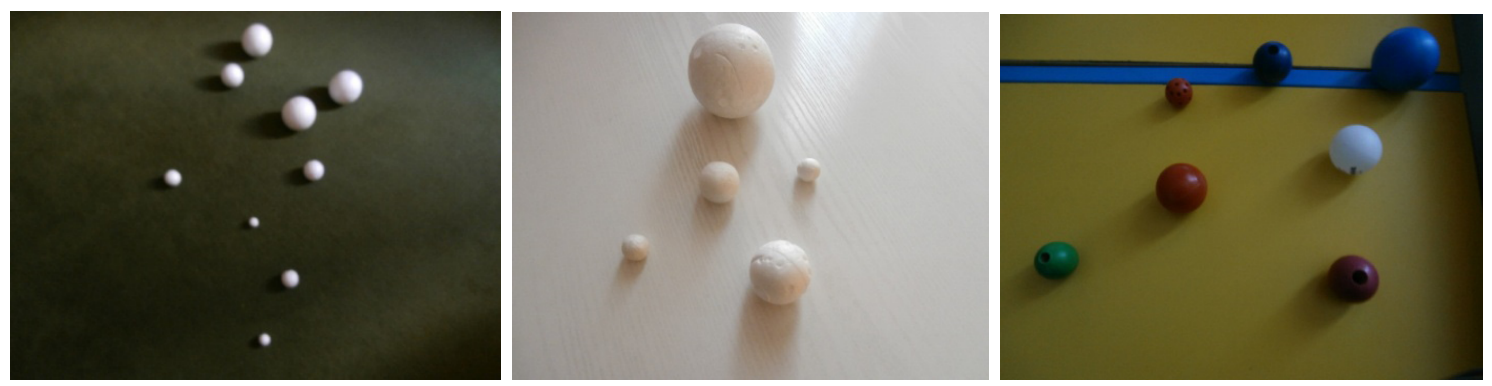

25., 26., 27. kép

A látótér fejlesztése pásztázós játékokkal lehetséges. Válassza ki a kedvenc játékát több tárgy közül, keressen meg egy általunk kért játékot. Sok szembetegség okoz látótérkiesést. $\mathrm{Az}$ a gyermek, aki látótérkieséssel küzd, nem lát bizonyos területeket maga körül; ezért nehezen vesz észre tárgyakat, ismer fel embereket. Szokatlan fejtartást figyelhetünk meg nála - hagyjuk, ne figyelmeztessük a helyes tartásra!

\section{A színek tanulása}

Fontos eleinte a megnevezés, az egyeztetés, a színtévesztés kizárása. Körülöttünk minden színes - könnyű olyan játékot találni, amely segít a színek egyeztetésében.

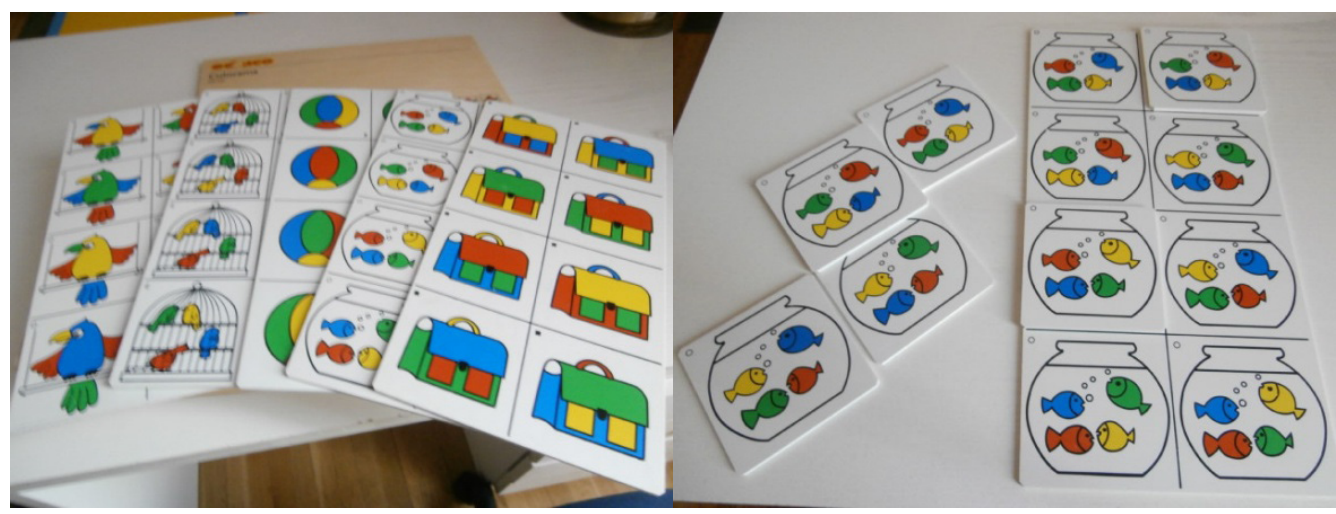

28. kép

A színek a formákkal, a képi ábrázolás felismerésével együtt gyakorolhatóak. 


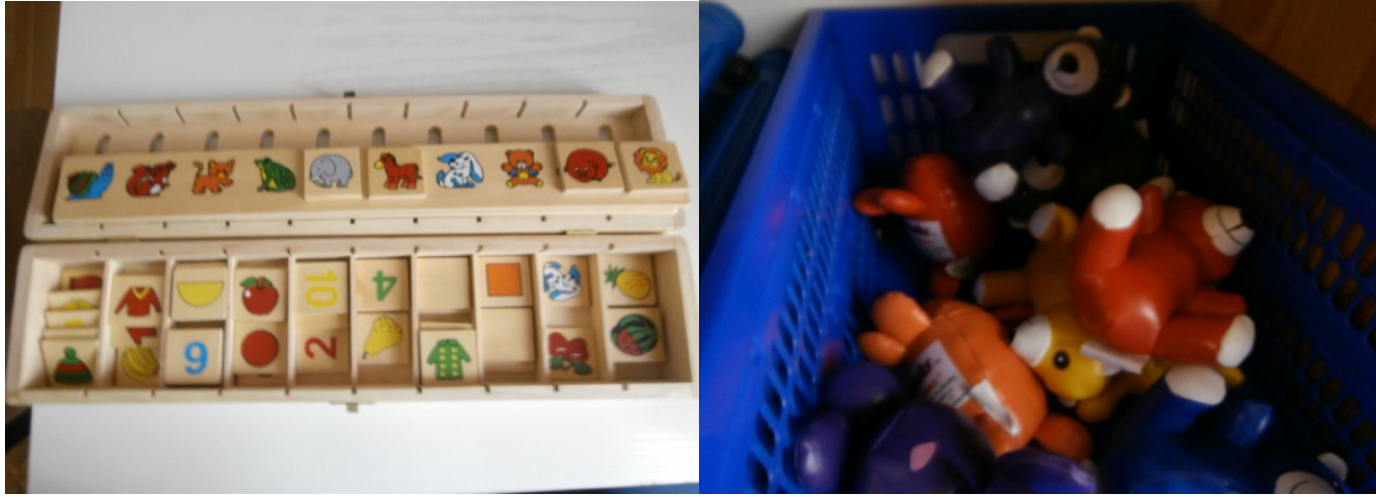

29., 30. kép: (fotó: Földiné)

\section{Szem-kéz koordinációt ügyesítő játékok}

A Lili Nielsen-féle kis szoba olyan gyermekek számára hasznos, akik fekvő helyzetben képesek felfedezni környezetüket, s megismerésüket segíti az, hogy a tárgyaknak álladó, rögzített helye van. A véletlenszerü felfedezésből lesz később a tudatos felényúlás, keresés, pásztázás, szem-kéz koordináció...

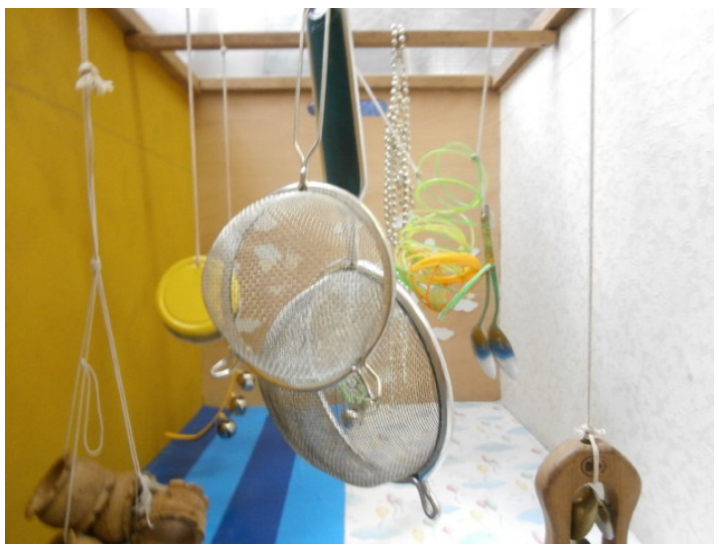

31. kép: (fotó: Földiné)

Eszközök még: karcsörgő, ujjbábok, labdák, babzsákok, papír (gyűréshez), építőjátékok, gyurma, magvak, pötyi, ruhacsipesz, kugli, füzőjátékok, horgász-játék, célbadobós játékok, formaegyeztetők stb.
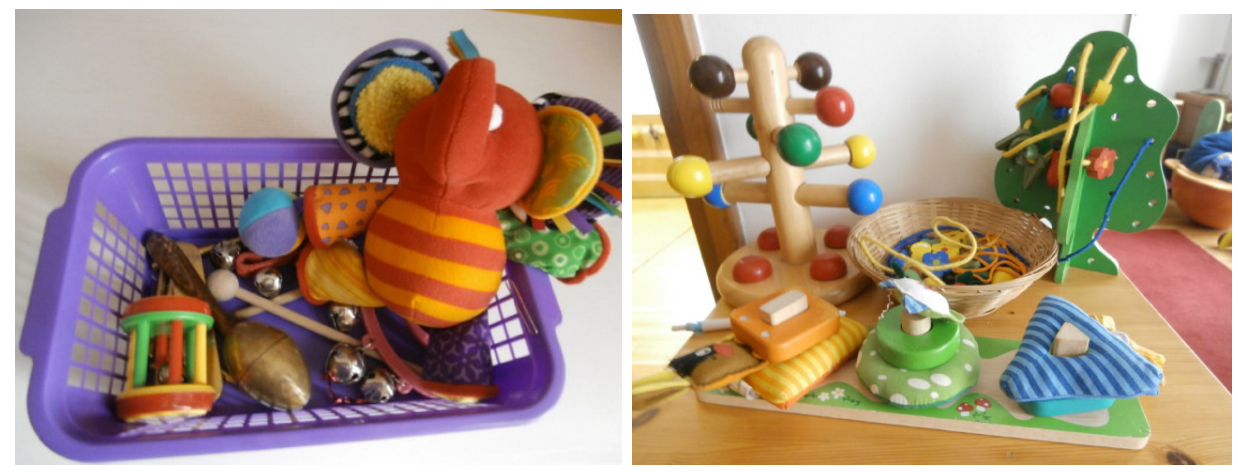

32., 33. kép: (fotó: Földiné) 


\section{Vizuális részképességek fejlesztését szolgáló játékok}

\section{A vizuális figyelem}

- Utánzás (szemtől-szembe, tükör előtt

- Mi változott játék: pl. babán, saját magunkon változtatunk valamit - rá kell jöjjön a gyermek, mi történt (pl. hajunkból kivesszük a csatot, levesszük a baba cipőjét stb.)

- Több tárgy közül válassza ki azt, amivel szeretne játszani - után a felnőtt kérjen tőle valamit.

- Minden tárgyról beszéljünk is (szín, forma, anyag, méret stb.), könnyítve ezzel a megismerést is. Ezek szerint a szempontok szerint lehet később válogatni.

- Tárgyképek alapján történő válogatás: kérem azt, amin víz van, amelyik állat repül, amelyik a kertben van stb.)

- Labirintus-játék

\section{A vizuális emlékezet}

Minden saját ötletủ és készen kapható memória-játék hasznos ebben a témában, de saját ötletekkel is lehet fejleszteni a gyermek ezen képességét. Adhat Ő is feladatot. Előzőleg bemutatott, majd elrejtett tárgyak felsorolása, egy tárgy eldugása közülük mi hiányzik stb.

Vizuális analízis-szintézis - szétszedés, összeillesztés, formatábla, kirakós játék, puzzle, minta utáni alkotás, építés.

Vigyázni kell a balesetek elkerülésére a diavetítő, az írásvetítő, a számítógép és a világító doboz használatánál. A túl sok fényinger kellemetlen érzetet, fáradtságot okozhat, ezért mindig figyelni kell a gyermek reakcióit.

Figyelembe kell venni a szemészeti megbetegedéseket, pl. Buphthalmus esetében nem szabad a gyermek szemébe világítani.

Epilepsziás megbetegedéseknél ki kell kérni a gyermekneurológus véleményét.

A látásnevelés már fényérzés esetén is a komplex fejlesztés része, de bizonyos esetekben az egységes fejlesztő foglalkozásból kiemelve, külön látásnevelő foglalkozás is lehet.

\section{Irodalom}

Az Egészségügyi Minisztérium szakmai irányelve A0-18 éves életkorú gyermekek látásfejlödésének követése, a kancsalság és a fénytörési hibák felismeréséröl. Szürővizsgálati irányelvek védőnők és gyermekorvosok számára Hivatalos értesítő, 2009. évi 46. szám, 8993-9005. URL: http://www.mave.hu/uploads/file/Latas\%20fejlodes.pdf

Földiné Angyalossy Zsuzsánna, Gadó Márta és Prónay Beáta (2012): Diagnosztikai kézikönyv „Látássérült (látásfogyatékos) gyermekek, tanulók komplex vizsgálatának diagnosztikus protokollja" Educatio Társadalmi Szolgáltató Nonprofit Kft., Budapest.

URL: http://www.educatio.hu/pub_bin/download/tamop_311/4piller/diagnosztikai_ kezikonyv_6fejezet.pdf

Koczor Ágnes (2012): Szemészeti szürővizsgálatok csecsemökorban.

URL: http://www.vital.hu/themes/sick/eyegyerekszem1.htm

Kovács Ilona (2005): A látás lassú fejlődése. Magyar Tudomány, 166. (11.) 1318-1327.

Kovács Krisztina: Nyújtsd a kezed! Tanácsadó kézikönyv látássérült kisgyermekek szüleinek számára. Látásvizsgáló Országos Szakértői és Rehabilitációs Bizottság, Budapest.

Magyar Zsuzsanna (2008): Látásnevelés In: Játsszunk most együtt - eszközkatalógus - a kiadvány a Fogyatékos Személyek Esélyegyenlőségéért Közalapítvány támogatásával készült

Mammel Andrea: A magzat, a csecsemő és a kisgyermekek látásának fejlődése.

URL: http://drmammel.extra.hu/latasfejlodes.htm 
Paraszkay Sára (2007): Közelröl nézve a gyengénlátó gyermek, Fer-Color Nyomda, Budapest.

Szandányi Judit (2012): Gyermekkorban jelentkező szembetegségek: látás, rövidlátás, kancsalság.

URL: http://www.vital.hu/themes/sick/child-suli3.htm

http://semmelweis.hu/szemeszet/a-szem-betegsegei/koraszulottek-ideghartya-karosodasa/

http://www.lea-test.fi/

http://www.northerngrid.org/resource/sen-switcher 